\title{
Collect Once, Use Many Times: Attaining Unified Metrics for Tuberculosis Preventive Treatment for People Living With HIV
}

Rena Fukunaga ${ }^{1}$, PhD, MA; David Lowrance ${ }^{2}$, MD; Adam MacNeil ${ }^{1}$, PhD; Teeb Al-Samarrai ${ }^{3}$, MD; Joseph Cavanaugh ${ }^{4}$, MD; Annabel Baddeley ${ }^{5}$, MD, MPH; Catherine Nichols ${ }^{6}$, DPH; Meaghan Peterson ${ }^{1}$, MPH; Sevim Ahmedov ${ }^{6}$, MD; Vindi Singh $^{2}$, MD; Celeste Gracia Edwards ${ }^{2}$, MD; Suman Jain ${ }^{2}$, MPH; Anand Date ${ }^{1}$, MD; Susan A Maloney ${ }^{1}$, MD, MHSc

\footnotetext{
${ }^{1}$ Centers for Disease Control and Prevention, Atlanta, GA, United States

${ }^{2}$ The Global Fund to Fight AIDS, Tuberculosis and Malaria, Geneva, Switzerland

${ }^{3}$ Office of the US Global AIDS Coordinator, Washington, DC, United States

${ }^{4}$ Walter Reed Army Institute of Research, Silver Spring, MD, United States

${ }^{5}$ World Health Organization, Geneva, Switzerland

${ }^{6}$ US Agency for International Development, Washington, DC, United States
}

\section{Corresponding Author:}

Rena Fukunaga, PhD, MA

Centers for Disease Control and Prevention

1600 Clifton Rd

Atlanta, GA, 30333

United States

Phone: 14046393311

Email:1xi9@cdc.gov

\begin{abstract}
The World Health Organization (WHO) recommends providing tuberculosis preventive treatment (TPT) to all persons living with HIV and to all household contacts of persons with bacteriologically confirmed pulmonary tuberculosis disease. Regrettably, the absence of a harmonized data collection and management approach to TPT indicators has contributed to programmatic challenges at local, national, and global levels. However, in April 2020, the WHO launched the Consolidated HIV Strategic Information Guidelines, with an updated set of priority indicators. These guidelines recommend that Ministries of Health collect, report, and use data on TPT completion in addition to TPT initiation. Both indicators are reflected in the WHO's list of 15 core indicators for program management and are also required by the US President's Emergency Plan for AIDS Relief's Monitoring, Evaluation, and Reporting (MER) guidance. Although not perfectly harmonized, both frameworks now share essential indicator characteristics. Aligned indicators are necessary for robust strategic and operational planning, resource allocation, and data communication. "Collect once, use many times" is a best practice for strategic information management. Building harmonized and sustainable health systems will enable countries to successfully maintain essential HIV, tuberculosis, and other health services while combatting new health threats.
\end{abstract}

(JMIR Public Health Surveill 2021;7(4):e27013) doi: 10.2196/27013

\section{KEYWORDS}

tuberculosis preventive treatment; monitoring and evaluation; people living with HIV; HIV; TB; infectious disease; preventative treatment

\section{Commentary}

Tuberculosis (TB) is the leading cause of death from a single infectious disease, with 1.2 million annual deaths worldwide and 10 million persons with incident TB estimated in 2019 [1]. To prevent TB disease in persons infected with HIV and at high risk for disease progression, the World Health Organization
(WHO) recommends providing tuberculosis preventive treatment (TPT) to all persons living with HIV (PLHIV) and to all household contacts of persons with bacteriologically confirmed pulmonary TB disease [2].

At the 2018 United Nations High-Level Meeting on TB, member states committed to ambitious targets for TPT scale-up, supporting the long-term goal of ending the global TB epidemic 
by 2030 . This pledge aims to provide TPT to at least 30 million people by 2022 (including 6 million PLHIV, 4 million children $<5$ years, and 20 million other household contacts of people affected by TB) [3,4]. Concomitantly, the US President's Emergency Plan for AIDS Relief (PEPFAR) committed to providing a course of TPT to all 13.6 million PLHIV on antiretroviral therapy (ART) supported by PEPFAR by 2021 [5]. The WHO's multisectoral TB accountability framework and HIV strategy also hold governments and stakeholders responsible for accelerating progress to end the TB epidemic and reduce TB-associated mortality among PLHIV including meeting the TPT targets [6]. In concert with these commitments, the Global Fund urges high TB/HIV burden countries to incorporate TPT into their funding requests and matches funds to incentivize country allocations for TPT scale-up among PLHIV [7].

Global reporting for 2019 showed gains in TPT scale-up among PLHIV, with 75 countries reporting initiation of TPT for 3.5 million individuals, up from 1.8 million in 2018 [1]. Examples of successful TPT expansion [8] demonstrate how resource-limited countries can overcome barriers, including modifying national and subnational health information systems (HIS) and monitoring and evaluation (M\&E) processes to accommodate TPT data collection and reporting [9]. However, these modifications remain more of an exception than the rule, as the absence of a harmonized data collection and management approach to TPT indicators has contributed to programmatic challenges at local, national, and global levels. This includes challenges in identifying impactful global health trends (a consequence commonly seen with data silos), in ensuring timely communication between programmatic stakeholders, and in enhancing the usability of the data in programmatically meaningful ways. Data reported to the WHO and PEPFAR entail parallel and varying reporting periods, indicator definitions, and partner engagement; harmonizing these efforts could help to decrease reporting burden and unify data metrics for programmatic decision making.

In April 2020, the WHO launched the Consolidated HIV Strategic Information Guidelines, with an updated set of priority indicators [10]. These guidelines recommend that Ministries of Health collect, report, and use data on TPT completion in addition to TPT initiation. Both TPT indicators are reflected in the WHO's list of 15 core, or highest priority, indicators for program management and monitoring and are also required by PEPFAR's Monitoring, Evaluation, and Reporting (MER) guidance [11]. Although not perfectly harmonized, both frameworks now share essential indicator characteristics (Table 1). Global Fund's modular performance framework uses the TPT initiation indicator to assess grant performance; while this alignment is only partial, it encourages countries to report TPT data as recommended by the WHO.

The ability to strengthen program management through improved data cannot be overstated. Robust data allow programs to identify geographic and sociodemographic differences in service coverage and quality and help ensure that no one is left behind. Aligned indicators are also necessary for robust strategic and operational planning, resource allocation, and data communication. Eliminating redundancies in the TPT data collection and management process will allow health care workers, data clerks, and TB and HIV program managers to reallocate their time toward optimizing service delivery and scale-up efforts, thereby becoming more efficient and effective. Simplified data collection methods may also reduce data entry errors and delays in reporting, although these benefits will not accrue immediately. National HIV and TB programs, which typically operate independently and use separate data systems, can strengthen their contributions by harmonizing metadata, M\&E tools, and digital data systems, making HIS interoperable across health sector programs, training staff on new data collection requirements, and capitalizing on movements toward primary and universal health care.

"Collect once, use many times" is a best practice for strategic information at local, national, and global levels. Application of this principle includes standards-based indicator alignment and coordinated resource allocation for national M\&E tools and HIS, along with concomitant coordination at the global level. It will eliminate parallel reporting systems and allow for the creation of a harmonized data set for use by partners at all levels. Such resilient, harmonized, and sustainable health systems will enable countries to successfully maintain essential HIV, TB, and other health services while combatting new health threats. 
Table 1. A comparison of the World Health Organization and US President's Emergency Plan for AIDS Relief's global tuberculosis/HIV indicators ${ }^{\mathrm{a}}$.

\begin{tabular}{|c|c|c|}
\hline Indicators & World Health Organization (and Global Fund) & US President's Emergency Plan for AIDS Relief (PEPFAR) \\
\hline Document name (version) & $\begin{array}{l}\text { Consolidated HIV Strategic Information Guidelines: } \\
\text { Driving Impact Through Programme Monitoring and } \\
\text { Management (April 2020) }\end{array}$ & $\begin{array}{l}\text { Monitoring, Evaluation, and Reporting Indicator Reference } \\
\text { Guide - MER 2.5 (September 2020) }\end{array}$ \\
\hline Description & $\begin{array}{l}\text { Proportion of patients receiving ART who started on a } \\
\text { standard course of TPT in the previous reporting period } \\
\text { who completed therapy }\end{array}$ & $\begin{array}{l}\text { Proportion of patients receiving ART who started on a } \\
\text { standard course of TPT in the previous reporting period } \\
\text { who completed therapy }\end{array}$ \\
\hline $\begin{array}{l}\text { Numerator (TPT comple- } \\
\text { tion) }\end{array}$ & $\begin{array}{l}\text { Number of PLHIV on ART who completed a course of } \\
\text { TPT among those who initiated TPT }\end{array}$ & $\begin{array}{l}\text { Among those who started a course of TPT in the previous } \\
\text { reporting period, the number that completed a full course } \\
\text { of therapy. For continuous IPT programs, this includes the } \\
\text { patients who have completed the first } 6 \text { months of IPT, or } \\
\text { any other standard course of TPT, such as } 3 \text { months of } \\
\text { weekly isoniazid and rifapentine, or } 3 \text {-HP. }\end{array}$ \\
\hline $\begin{array}{l}\text { Denominator (TPT initia- } \\
\text { tion) }\end{array}$ & Number of eligible PLHIV on ART who initiated TPT & $\begin{array}{l}\text { Number of patients on ART who were initiated on any } \\
\text { course of TPT during the previous reporting period }\end{array}$ \\
\hline $\begin{array}{l}\text { Data elements (disaggre- } \\
\text { gates) }\end{array}$ & $\begin{array}{l}\text { Descriptions: } \\
\text { - Sex: male, female, transgender } \\
\text { - } \quad \text { Age bands: }<15 \text { years, } \geq 15 \text { years } \\
\text { - } \quad \text { Type of TPT regimen } \\
\text { - } \text { ART initiation: }<12 \text { months on ART, } \geq 12 \text { months on } \\
\quad \text { ART }\end{array}$ & $\begin{array}{l}\text { Age/sex by ART start descriptions: } \\
\text { - Newly enrolled on ART: these individuals initiated } \\
\text { TPT within } 6 \text { months of being enrolled on ART } \\
\text { - } \quad \text { Previously enrolled on ART: these individuals initiated } \\
\text { TPT at least } 6 \text { months (or longer) after being enrolled } \\
\text { on ART } \\
\text { - Age/sex bands: }<15 \text { years female/male, } \geq 15 \text { years fe- } \\
\text { male/male, unknown age female/male }\end{array}$ \\
\hline Reporting level & Facility & Facility \\
\hline Reporting frequency & Quarterly, semiannually, and/or annually & $\begin{array}{l}\text { Semiannually, with results encompassing achievements } \\
\text { from October 1-March } 31 \text { and April 1-September } 30\end{array}$ \\
\hline Most recent changes & New indicator in 2020. & No changes between MER v2.4 to v2.5. \\
\hline
\end{tabular}

${ }^{\mathrm{a}}$ ART: antiretroviral therapy; IPT: isoniazid preventive therapy; MER: monitoring, evaluation, and reporting guidance; PLHIV: persons living with HIV; TPT: tuberculosis preventive treatment.

\section{Disclaimer}

The authors alone are responsible for the views expressed in this article and they do not necessarily represent the views, decisions or policies of the institutions with which they are affiliated.

\section{Conflicts of Interest}

None declared.

\section{References}

1. World Health Organization. Global Tuberculosis Report 2020. Geneva: World Health Organization; 2020 Oct 14. URL: https://www.who.int/publications/i/item/9789240013131 [accessed 2020-10-15]

2. World Health Organization. WHO Consolidated guidelines on tuberculosis: module 1: prevention. Geneva: World Health Organization; 2020. URL: https://tinyurl.com/tjxyrntk [accessed 2020-10-15]

3. United Nations. Political declaration of the high-level meeting of the United Nations General Assembly on the fight against tuberculosis. 2018 Oct 10. URL: https://www.who.int/tb/unhlmonTBDeclaration.pdf [accessed 2020-10-15]

4. World Health Organization. The END TB Strategy. Global strategy and targets for tuberculosis prevention, care and control after 2015. Geneva: World Health Organization; 2014. URL: https://tinyurl.com/59s744tn [accessed 2020-10-15]

5. U.S. President's Emergency Plan for AIDS Relief. PEPFAR 2020 Country Operational Plan Guidance for all PEPFAR Countries. 2020. URL: https://www.state.gov/wp-content/uploads/2020/01/COP20-Guidance Final-1-15-2020.pdf [accessed 2020-01-20]

6. World Health Organization. Multisectoral Accountability Framework to Accelerate Progress to End Tuberculosis by 2030. Geneva: World Health Organization; 2019 May. URL: https://www.who.int/tb/publications/MultisectoralAccountability/ en/ [accessed 2020-10-15] 
7. Global Fund. Guidance Note: Matching Funds 2020-2022 Funding Cycle. Geneva, Switzerland: Global Fund; 2020 May. URL: https://www.theglobalfund.org/media/9372/fundingmodel 2020-2022matchingfunds guidance en.pdf [accessed 2020-10-15]

8. Melgar M, Nichols C, Cavanaugh JS, Kirking HL, Surie D, Date A, CDC Country Offices' Tuberculosis/HIV Advisors, National Ministries and Departments of Health Tuberculosis Program Managers. Tuberculosis Preventive Treatment Scale-Up Among Antiretroviral Therapy Patients - 16 Countries Supported by the U.S. President's Emergency Plan for AIDS Relief, 2017-2019. MMWR Morb Mortal Wkly Rep 2020 Mar 27;69(12):329-334 [FREE Full text] [doi: 10.15585/mmwr.mm6912a3] [Medline: 32214084]

9. Pathmanathan I, Ahmedov S, Pevzner E, Anyalechi G, Modi S, Kirking H, et al. TB preventive therapy for people living with HIV: key considerations for scale-up in resource-limited settings. Int J Tuberc Lung Dis 2018 Jun 01;22(6):596-605 [FREE Full text] [doi: 10.5588/ijtld.17.0758] [Medline: 29862942]

10. World Health Organization. Consolidated HIV strategic information guidelines. Geneva: World Health Organization; 2020 Apr 10. URL: https://www.who.int/publications/i/item/9789240000735 [accessed 2020-10-15]

11. Monitoring, Evaluation, and Reporting Indicator Reference Guide. MER 2.0 (Version 2.5). Washington, DC, USA: PEPFAR; 2020 Sep. URL: https://datim.zendesk.com/hc/en-us/articles/360000084446-MER-Indicator-Reference-Guides [accessed 2020-10-10]

\author{
Abbreviations \\ ART: antiretroviral therapy \\ HIS: health information system \\ MER: Monitoring, Evaluation, and Reporting \\ M\&E: monitoring and evaluation \\ PEPFAR: US President's Emergency Plan for AIDS Relief \\ PLHIV: persons living with HIV \\ TB: tuberculosis \\ TPT: tuberculosis preventive treatment \\ WHO: World Health Organization
}

\author{
Edited by Y Khader; submitted 07.01.21; peer-reviewed by AAS Sawitri, Y Cai, A Sudaryanto; comments to author 04.03.21; revised \\ version received 12.03.21; accepted 14.03.21; published 30.04.21 \\ Please cite as: \\ Fukunaga R, Lowrance D, MacNeil A, Al-Samarrai T, Cavanaugh J, Baddeley A, Nichols C, Peterson M, Ahmedov S, Singh V, Edwards \\ $C G$, Jain S, Date A, Maloney SA \\ Collect Once, Use Many Times: Attaining Unified Metrics for Tuberculosis Preventive Treatment for People Living With HIV \\ JMIR Public Health Surveill 2021;7(4):e27013 \\ URL: https://publichealth.jmir.org/2021/4/e27013 \\ doi: $10.2196 / 27013$ \\ PMID:
}

CRena Fukunaga, David Lowrance, Adam MacNeil, Teeb Al-Samarrai, Joseph Cavanaugh, Annabel Baddeley, Catherine Nichols, Meaghan Peterson, Sevim Ahmedov, Vindi Singh, Celeste Gracia Edwards, Suman Jain, Anand Date, Susan A Maloney. Originally published in JMIR Public Health and Surveillance (https://publichealth.jmir.org), 30.04.2021. This is an open access article distributed under the terms of the Creative Commons Attribution IGO License (http://creativecommons.org/licenses/by/3.0/igo/legalcode), which permits unrestricted use, distribution, and reproduction in any medium, provided the original work is properly cited. In any reproduction of this article there should not be any suggestion that WHO or this article endorse any specific organisation or products. The use of the WHO logo is not permitted. This notice should be preserved along with the article's original URL. 